\title{
Resilience and permanence of public values: an analysis of administrative contracts in Brazil
}

\author{
Fernanda Alves AndRade Guarido ${ }^{1}$ \\ ELOY EROS DA SILVA NOGUEIRA ${ }^{2}$ \\ Mayla Cristina Costa Maroni Saraiva ${ }^{3}$ \\ ${ }^{1}$ Instituto Brasileiro de Estudos e Pesquisas SOCIAIS (IBEPES), CURITIBA - PR, BRAZIL \\ 2 Universidade Positivo / Programa de Mestrado e Doutorado em Administração, Curitiba - PR, Brazil

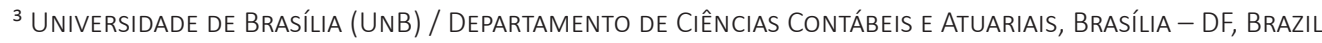

\begin{abstract}
This article analyzes the resilience of the public values in the Brazilian public administration's management models, considering the rules adopted in administrative contracts. This sociological research argues that such public values reflect society's normative and cultural standards. The study's theoretical relevance lies in its contribution to understanding the cultural dimension of Brazilian society, recognizing that the law reflects normative standards given the environment in which it is elaborated and enforced. In practice, the study seeks to foster the comprehension of rules, their purposes, and the public ethos that gives identity to the administration. The values attributed to the management models observed in a historical framework were dialogicity, modernization, efficiency, productivity, and professionalization. Finally, administrative contracts are technologies with characteristics of historical models of public management and represent a normative standard that needs improvements.
\end{abstract}

Keywords: Public values. Administrative contracts. Resilience.

\section{Resiliência nos valores públicos e sua permanência: uma análise dos contratos administrativos no Brasil}

\section{Resumo}

O objetivo foi analisar a resiliência dos valores públicos presentes nos modelos de gestão da administração pública brasileira, por meio das normas elaboradas para os contratos administrativos. A pesquisa tem um viés sociológico, sustentando que tais valores públicos refletem os padrões normativos e culturais da sociedade. Tem relevância teórica por contribuir para a compreensão cultural, ao afirmar, entre outras coisas, que a lei reflete padrões normativos dado o meio em que é elaborada e aplicada. Na prática, pretende-se fomentar a compreensão das normas, seus propósitos e o ethos público que dá identidade à administração. Os valores atribuídos aos três modelos históricos de gestão foram identificados como dialogicidade, modernização, eficiência, produtividade e profissionalização. Por fim, considera-se que os contratos administrativos são tecnologias que carregam os traços dos modelos históricos de gestão pública e representam um padrão normativo que precisa ser atualizado.

Palavras-chave: Valores públicos. Contratos administrativos. Resiliência.

\section{Resiliencia de los valores públicos y su permanencia: un análisis de dos contratos administrativos en Brasil}

\section{Resumen}

El objetivo fue analizar la resiliencia de los valores públicos presentes en los modelos de gestión de la administración pública brasileña, a través de las reglas elaboradas para los contratos administrativos. La investigación tiene un sesgo sociológico al afirmar que tales valores públicos reflejan los estándares normativos y culturales de la sociedad. Tiene relevancia teórica por contribuir a la comprensión cultural, al afirmar, entre otras cosas, que la ley refleja estándares normativos dado el medio en que se elabora y aplica. En la práctica, se pretende fomentar la comprensión de las normas, sus propósitos y el ethos público que da identidad a la administración. Los valores atribuidos a los tres modelos históricos de gestión fueron identificados como dialogicidad, modernización, eficiencia, productividad y profesionalización. Finalmente, se considera que los contratos administrativos son tecnologías que cargan los rasgos de los modelos históricos de gestión pública y representan un estándar normativo que necesita actualización.

Palabras clave: Valores públicos. Contratos administrativos. Resiliencia. 


\section{INTRODUCTION}

This article aims to analyze the resilience of public values, through the rules in force for administrative contracts, in relation to the values of historical models of public management practiced in Brazil. Therefore, it admits that the management models (Secchi, 2009) available to public managers are subject to cultural influences from the environment in which they are implemented, thus acquiring their own contours. Reality, at the moment it is produced, not only copies references, but also constitutes them and transforms them, under the influence of situations, values, and beliefs experienced in time and space (Coraiola, Jacometti \& Gonçalves, 2015; Davis \& Scott, 2007; Streeck \& Thelen, 2005). It is also considered that, in Brazilian society, there are both tangible and intangible goods of general interest. Such assets acquire the status of public values and should be protected and provided by public policies developed by the government.

Public policy models, which have been analyzed as the set of decisions and actions related to the imperative allocation of values of a given political actor (Souza, 2003), are now seen as a complex set of arrangements made up of many actors, in which the role of decision-making institutions, power relations, ideas, values, and time is inherent (Almeida, Lia \& Gomes, 2019; Sabatier, 2007).

The way in which these values are delivered and the actors who participate in this process are influenced by the management models adopted in public administration, which are not separated from one another (Dellagnelo \& Machado-da-Silva, 2000), but are both transformed in the doing and conceiving in the field. Public values, in themselves, persist and may evolve, but do not lose their essence (Moore, 2007).

The theoretical relevance lies in the approximation between the cultural aspect (values, beliefs, and normative expectations), as part of the orientation individuals and organizations refer to understand daily life and organize activities (Haveman \& Gualtieri, 2017), expressed in research by the adoption of organizational institutionalism as a theoretical lens and praxis (Scott, 2014; Scott \& Meyer, 1994).

The connection between these elements occurs through the verification of the influence of cultural and normative patterns in the creation of rules and the dissemination of processes in the Brazilian Public Administration. In other words, the research investigated how the practice, through the rules elaborated for administrative contracts, reflects social values, if the law is a cultural expression, and if there are public values that guide the actions, which should be satisfied, despite the historical changes that have occurred in the management models adopted. To elaborate, there is a core of public values linked to normative standards coming from a society that, while in force, will be prioritized in public management, changing only the way of providing them, the participation of actors, and other elements. The practical relevance, as argued, lies in broadening the understanding of the composition of the rules and their purposes, and, in a greater unfolding, in the understanding of the public ethos (Lavalle, 2001) that gives identity to the Brazilian Public Administration.

To this end, the contractual models existing in the general legislation: Law No. 8,666 of 1993, in the General Law of Concessions; Law No. 8,987 of 1995; and in the Public-Private Partnerships Law, Law No. 11,079 of 2004 were compared. We gave a step before and analyzed the Decree-Law No. 2,300, dated 1986. But we gave a step forward too. On December 10, 2020, Bill No. 4,253 of 2020 was approved by the Senate, and at 01.04 .2021 , it was converted into Law No. 14,133, this is the new Brazilian administrative contracts law, so we considered important to analyze it also.

Assuming that such laws are an expression of the shared culture, values, and beliefs in Brazilian society and its public administration, we believe in the usefulness of the analysis performed in terms of contextualizing the present, understanding it through knowledge of the past, and understanding the systemic character of social phenomena (Deephouse, Bundy, Tost \& Suchman, 2017). The basis of the research premise is that the rules stated in the laws, as discipline elements of relationships and processes, reflect societal normative standards. 


\section{THEORETICAL REFERENTIAL}

\section{Public values and their identification within the state}

The modern state, as conceived, is characterized as a collective entity, embodied in a legal entity whose purpose is to perform functions of interest to its constituents. In order to exist, it requires people with common interests and wills, occupying a given territory and conferring sovereignty on the state entity (Bastos, 2002). In essence, these people constitute the state entity according to what they value.

People require individual satisfactions, which, as a result of living in a society, are collectively shaped (Berger \& Luckman, 1985). Therefore, the state, given its intended functions, synthesizes the collective will, with the task of realizing it. Some authors claim that the state embodies public interests (Bandeira-de-Mello, 1983), that is, assets recognized, identified, and valued as relevant, both on an individual and collective level. Caillé (2008) points out that the articulation between individualism and holism is necessary to recognize what is considered socially relevant.

Public values thus represent the recognition of something that is good and that should be sought for the benefit of the community. It is the act of recognizing this good and its ability to be a donor and creditor of something of interest to this collectivity that gives it value (Caillé interpretation, 2008). Indeed, public policies can be understood as the set of decisions and actions related to the imperative allocation of values of a given political actor (Souza, 2003), or more recently, as a set of arrangements made up of many actors, in which the role of decision-making institutions, power relations, ideas, values, and time is inherent (Almeida et al., 2019; Campbell, 2002; Sabatier, 2007).

Moore (2007) proposed three distinct meanings of public values. He first defined them as the sum of individual satisfactions produced by a social system or government policy. Secondly, they were conceived as the purposes of a citizen-acting government, realized through government powers and resources. And thirdly, public values were considered the purposes collectively achieved by the government, thus generating individual satisfaction (Moore, 2007, p. 170). Caillés (2008) ideas about gratitude are present in the concept of public values because, by having an individual satisfaction provided, the citizen is a creditor and donor in appreciation of the importance attributed to the good. These acts of recognition provide the actions, and therefore public values can trigger practical attitudes.

Such actions can enter the political sphere (Moore, 2007) when guided by the sharing of an identity, which includes, for example, the notion of justice and adequacy by political actors (Moore, 2007). Considering that the state, a legal entity that represents the interests of a given collectivity, has tangible and intangible assets that it protects and aims to realize, and that such assets are shared by this collectivity, it can be said that public values represent the standards that guide behavior in promoting political or civic actions.

Such values may thus be present in standards of conduct, in process prescriptions, and in the definition of structures. As both the medium and the goal, they can shape beliefs and define actions. In this conception, public values can constitute the identity of the administration, shape the existing culture, and outline the contours of management. However, they can also be management objects.

\section{Brazilian Public Administration and its management models in an Historical and Institutional Framework}

Authors of the organizational institutionalism consider that cultural concepts participate in the development of practices and structures that are the expressions of actors' negotiation or imposition on each other constituting organized life, through the creation of meanings, development of identities, legitimation parameters that contribute together with material practices to the constitution of historical that are in a social context (Haveman \& Gualtieri, 2017; Micelotta, Lounsbury \& Greenwood, 2017; Orlitzky, 2011).

Before becoming a republic, Brazil was a colony of Portugal, possessing a king and divided into hereditary captaincies (Calmon, 2002). The functions of the grantee, that was the highest authority, were legal and administrative, allowing them to make judgments, impose sanctions, distribute his land, found villages, enslave Indians, collect taxes, etc., and pass a portion of 
these to the crown (Calmon, 2002). The management was patrimonial, therefore, as far as the captaincy represents a good of use and exploitation of the dealer. At this moment the public was of propriety, being privately owned.

In 1821, the captaincies were extinguished, becoming provinces. A year later, Brazil became an independent empire of Portugal, and was subsequently endowed with a written constitution, the 1824 Constitution, which, in addition to the three traditional powers, instituted a moderating power (Bastos, 2002). The Constitution of 1824 brought a sequelae of absolutism, despite being liberal and, in practice, allowed the exercise of a parliamentary system in Brazil (Bastos, 2002).

After becoming a republic, Brazil went through a period of political clashes, authoritarian regimes, and coups. It had four constitutions (from empire to republic: 1934, 1937, 1946, and 1967) until the advent of the Brazil's 1988 Constitution. Brasil, Cepêda e Medeiros (2014) claim that, after the break with the Portuguese court, Brazil had a political system dominated by two groups: on the one hand, patriarchal families, and, on the other hand, a central state mediating the public interests. In the first group, the relations were consanguineous and clientelist; in the second, the different interests of groups and regions were reconciled (Brasil et al., 2014).

Until 1930, Brazil lived under the strong influence of this culture and politics, with elements of mandonismo (a Brazilianism, used in political science, philosophy and sociology, to define one of the characteristics of the exercise of power by oligarchic and personalized structures, equivalent in the Hispanic literature to the so-called caciquism), nepotism, clientelism, and patrimonialism (Brasil et al., 2014; Carvalho, 1997), which permeated the state and administrative apparatus (Brasil et al., 2014).

From 1930 on, industrial development began to take place in Brazil, which impelled the state to assume the role of development inducer (Brasil et al., 2014). Thus, the consolidation of the Weberian bureaucracy began (Brasil et al., 2014). Abu-El-Haj (2005) points out that the rational-public administration is characterized by the hierarchization and rationalization of functions, the division of labor, the limited authority of positions, the existence of written norms, the specialization of the professions, the existence of stable careers, written and documented communication, and the separation between public goods and server property.

A relevant historical fact in the trajectory of the Brazilian Public Administration is the creation of the Administrative Department of the Public Service (DASP) in the Constitution of 1937 (Pinto \& Santos, 2017). One of the main tasks of the DASP was the implementation of administrative reform (Brasil et al., 2014), and it was also responsible for the budget organization, job classification, and career structuring of employees (Pinto \& Santos, 2017). The social advances made in Brazil from 1930 to 1937 suffered from the authoritarianism of the governor at that time, Getúlio Vargas (Abu-El-Haj, 2005). However, according to Abu-el-Haj (2005, p. 39), the DASP "left the embryo of a new public ethic" with "basic notions of a 'universal public', a rational state at the service of society's general welfare and a concept public institution, resistant to political manipulation."

In 1967, under the presidency of Juscelino Kubitschek, another important reform began in the Brazilian Public Administration. By this time, Brazil had already established itself as an industrial nation (Abu-El-Haj, 2005) and was maximizing its economic development. The reform took place on two fronts, the economic and the social. In prioritizing the first arena, the focus was on import substitution and improving basic infrastructure (Abu-El-Haj, 2005).

Decree-Law No. 200 of 1967 formalized state reform at the time, creating decentralized management, and management entities were created to carry out the business functions (Abu-El-Haj, 2005). However, the strong focus on economic rather than social development has caused some problems. State growth and indebtedness, with the creation of state-owned and subsidized services, and the oil crisis, among other factors, led to the need to revise the pillars under which management operated (Abu-El-Haj, 2005).

The 1988 political Charter gave Brazil the status of the democratic rule of law, in which the ruler submits to the law, popular will, and purposes proposed by the citizens (Bastos, 2002). This Constitution, according to Abu-El-Haj (2005, p. 46), "raised new hopes for economic development with social justice." Eight economic plans marked the 1980s and early 1990s. Abu-El-Haj (2005) points out that inflation and difficulties in resuming economic development are the factors that led President Fernando Henrique Cardoso to propose the third reform of state and public administration. In 1995, the Ministry of Federal Administration and Reform (MARE) was instituted, in charge of the Master Plan for Reform of the State Apparatus (PDRAE). 
The reform guidelines instituted by the PDRAE were destatization, rationalization, flexibility, institutionalization, and publicization (Pinto \& Santos, 2017). Actions typical of this managerial reform included accountability, increased efficiency through the pursuit of productivity, privatization, outsourcing and deregulation, transfer of non-exclusive services to non-state public entities, and so on (Costa, 2008).

Managerial reform is considered the modernization of public administration, due to the financial and administrative autonomy it brings to public entities, the flexibility and control it provides, the search for results, and the secondary role it attributes to stability (Abu-EI-Haj, 2005). For Bresser-Pereira (1996), it has become a condition for "a modern, professional and efficient public service, focused on meeting the needs of citizens" (Bresser-Pereira, 1996, p. 296).

Brazilian society has lived with the legal and administrative regime of the 1988 Constitution for over 30 years. Nevertheless, the management of this system reflects the milestones of its history. In present times, in materializing the many precepts of the 1988 political Charter, there is a growing horizontalization of public management, which is seen in the creation of councils, participatory budgets, new forms of contracting with the public power, popular initiatives in the proposition of laws, and so forth (Pinto \& Santos, 2017; Secchi, 2009). There is talk of citizens whose individual identities are associated with the polis (Gurgel, 2017). To represent this movement, therefore, Pinto and Santos (2017) adopted the term "societal public administration."

Secchi (2009) states that a plurality of names is attributed to management models and classified these as: (1) the bureaucratic model, (2) the managerial public administration, and (3) the public governance. The author states that the models failed, which does not mean they disintegrated, as they still coexist today. From Secchi (2009), it can be stated that the criticism of the models led to the emergence of new forms of management. Thus, while the bureaucratic model has set an exceptional standard of expertise among workers in organizations, its dysfunctions are many, such as the impact of strict prescriptions on employee motivation, resistance to change, abuse of corporatism, and so on, led to the attempt to overcome such problems.

Thus, models of managerial public administration and entrepreneurial government are reactions to the dysfunctions of the bureaucratic model (Secchi, 2009). The values of productivity, service orientation, decentralization, service efficiency, marketization, and accountability are attributed to the management model (Secchi, 2009). However, public governance was conceived as a relational model, focused on the collective construction of public policies (Secchi, 2009).

In terms of theorizing, public management in Brazil followed a trajectory of stages and was marked by the predominant understandings that they constituted, which were as: (1) a legal science, (2) an administrative science, (3) a public administration (Keinert, 1994). The idea prevailed in the first conception that the administration should act for the creation of laws; in the second, it was believed that public and private administrations should act similarly, while in the third, it admitted the existence of contours peculiar to public administration (Keinert, 1994). The different paradigms are summarized in Box 1:

Box 1

Paradigmatic Periods

\begin{tabular}{|c|c|c|c|c|}
\hline Periods & Institutional context & Paradigms & Phases & $\begin{array}{c}\text { Characteristics of Public } \\
\text { Administration Field }\end{array}$ \\
\hline $1900-1929$ & Liberal Regulatory State & $\begin{array}{c}\text { Public Administration } \\
\text { as Legal Science }\end{array}$ & Legalism \\
\hline $1930-1979$ & $\begin{array}{c}\text { 2. Administration for development } \\
\text { 1. Administrative Status }\end{array}$ & $\begin{array}{c}\text { Public Administration as } \\
\text { Administrative Science }\end{array}$ & $\begin{array}{c}1930-1945 \\
1946-1964\end{array}$ & $\begin{array}{c}\text { Rationalization } \\
\text { Development } \\
\text { Rationality and } \\
\text { technical competence }\end{array}$ \\
\hline $1980-1989$ & Social Mobilization & $\begin{array}{c}\text { Public Administration } \\
\text { as Political Science }\end{array}$ & & $\begin{array}{c}\text { Democratization } \\
\text { Conflict of interests } \\
\text { Scarce resources }\end{array}$ \\
\hline $1990 * * *$ & State role redefinition & $\begin{array}{c}\text { Public Administration as } \\
\text { Public Administration }\end{array}$ & & $\begin{array}{c}\text { Political capacity } \\
\text { combined with technical } \\
\text { competence }\end{array}$ \\
\hline
\end{tabular}

Source: Keinert (1994, p. 43). 
The synthesis of Keinert (1994) highlights the historical moments that Brazil has gone through, along with the importation of rules, the effort for efficiency, and the effort to politicize public management. If, on the one hand, public management coexists today with traces of the models synthesized here, on the other hand, the models have existed for a long time in Brazilian history, and they can be identified in rules, plans, reforms, and constitutional texts. The fact that these models have persisted over time can be considered as conducive to the internalization and aggregation of normative standards. The management models and the values underpinning them thus persist in Brazilian culture, shaping the identity of Brazilian managers and their modes of action.

When we analyze the Constitutions and laws of administrative contracts in Brazil based on organizational institutionalism, it is important to verify that the values are historically reflex of the actors who organize themselves in groups and start to exert influence (Greenwood et al., 2011). Social actors trust their understanding of institutional logic in the competition for power and status and generate the conditions for the reproduction of the prevailing logic. At the same time, different actors continue to maintain their different logics, and it can be concluded that competition or tension between multiple logics is continuous (Goodrick \& Reay, 2011). But some values perpetuate by normative acts.

\section{METHODOLOGY}

The strategy chosen was the historical research. Suddaby, Greenwood (2009, p. 187) argue that the purpose of historical methodology is to identify stages and continuity, diversity and change and to analyze how historical conditions produce institutional configurations and their variations. The scope of the research is to verify the resilience of public values. So, to analyze their permanence along the time is important. Indeed, the past, the present and the future was embraced for the data selected.

The methodology is qualitative, with a descriptive scope. It was combined bibliographic and documentary analysis. The bibliographic material was selected from papers publicized by Brazilian Public Management Academy. The papers were extracted of www.spell.org.br. The historical literature about Brazil were selected. The material served to describe the Brazilian culture, Brazilian models of management, and to identify the resilient public values on that models.

The data were selected on the legislation about administrative contracts since the Decree-Law No. 2,300, dated 21.11.1986 which was in force until 20.06.1993; the Law No. 8,666, dated 21.06.1993; the Law No. 11,079, dated 30.12.2004; the Law No. 8,974, dated 05.01.1995. The Law Project No. 4,253, dated 2020, recently converted into Law No. 14,133, dated 01.04.2021 was selected too. It was made content analysis on the legislation using the public values identified on the theories about public administration.

The resilient public values were identified in the theory about public management by thematic association (Bardin, 2011). It was reading the text of the law selected that the narratives revealed the presence or not of the analytic categories. The purpose was to identify commands, orders, or reasons which have relation with some of the public values acquired on theory.

The legislation above-mentioned were selected, in their compiled versions, that is, considering all the changes that have been made in their texts since their original editions. The resilience of values in the bureaucratic, managerial, and public governance models were considered in the data classification.

In order not to expand the scope too much, other rules, such as those that govern covenants, terms of partnerships, terms of collaboration, and funding, were not part of the research. Such rules characterize the means of the relationships between the public power and non-profit, public, non-governmental organizations, among others. Thus, the research focused on the works, services, and procurement contracts resulting from public bids or legal exceptions to the bidding procedure. These rules apply to contracts signed with private companies and are, at this point, broader than the legislations that do not fit the research. 


\section{ANALYSIS AND DISCUSSION OF RESULTS}

\section{Cultural characteristics of Brazilian society with possible impact on public management}

Brazil was a caste society after discovered by a Portuguese explorer, who colonized it as an extension of Portugal, in which masters and slaves lived in the same space, a large house with its slave-arranged housing (Holanda, Eulálio \& Ribeiro, 1995). The social classification went from (1) settlers and exiles, to (2) Portuguese, Indians, and mestizos, and finally to (3) whites, browns, and blacks (Calmon, 2002). In this society, the nobility was known for their skin color, the number of slaves they owned, and their idleness, since working was the task of the unfortunate (Calmon, 2002). Being a Portuguese colony, Brazil had a general government, but there were local councils that exercised public management in the towns and cities, with captains-customs and heads of household as the managers in the two zones of influence, respectively (Calmon, 2002).

Private property influenced the relationships between people (Viana, 2005). An individual's value was denoted according to his peculiar abilities, which favored the crony (Holanda et al., 1995). "Cunhadismo", that is, the family relationship that was established with the tribe by the Portuguese's marriage with an Indian led the tribe to work for this foreigner (Ribeiro, 1995), that became part of the same family. Patrimonialism and relationships based on affectivity were typical of the colonizer of Hispanic culture and were striking in the relations of the first inhabitants of Brazil (Holanda et al., 1995).

The growth of cities was late, and there were frequent manifestations of individualism that marked Brazil's development (Oliveira \& Gimenes, 2010). The public was a place of deception, a "no man's land" (Matta 1986). Its formation was influenced by patrimonialism, the differences between the existing classes, and the authority of the lords of possessions (Matta, 1986; Holanda et. al., 1995; Viana, 2005). The formation of the public sphere in Brazil has therefore been characterized by the invasion of the private sphere. Matta (1986) states that duality is a characteristic feature of the formation of public space, and therefore of Brazilian society. The democratization process, for example, was granted (Holanda et al., 1995). Moreover, Brazilian history was marked by the alternation of liberal governments and other more centralizing and authoritarian governments (Abu-El-Haj, 2005) until the advent of the Brazil's 1988 Constitution.

According to Prestes-Motta and Alcadipani (1999), societal relations in Brazil are marked by paternalism and decisions based on emotional factors, thus exhibiting an overlapping of love and hate and economic-rational attitudes. In this sense, the Brazilian society reflects polite attitudes, an aversion to hierarchical and unequal social ritualisms, and a culture of personality, in which what is personally intimate overrides the interests of the collectivity (Prestes-Motta \& Alcadipani, 1999). Hence, there exists the "jeitinho," that is, the process by which the Brazilian seeks a personal solution, despite contrary general determinations (Prestes-Motta \& Alcadipani, 1999).

Another feature of Brazilian society is formalism, explained by Machado-da-Silva, Guarido, Nascimento and Oliveira (2003) as the existence of a formal reality and another concrete one. Thus, the country imports legislation, like the republic itself, even though it internally cultivates personalistic relations; for example, Brazil had slavery internally while being capitalist in its international trade relations (Machado-da-Silva et al., 2003). Castor (2013) lists the Brazilian cultural traits of mistrust as a method, bureaucratic centralism, and state dependence. The mistrust leads to excessive formalities aimed at controlling relations. Moreover, Brazil's bureaucratic centralism is inherited from the Portuguese, who established rules that invaded the private sphere of its subjects, and the dependence of the state consists in waiting for solutions from the state apparatus.

Prestes-Motta and Alcadipani (1999) state that culture can function as a mechanism of social control. Thus, the cultural characteristics mentioned above may function as control mechanisms influencing the state's modes of action, that is, the way the nation is politically organized (Castor, 2013). Patrimonialism, "cunhadismo", formalism, bureaucratic centralism, distrust, and dependence of the state are Brazilian cultural traits that may have influenced public management, since they represent important aspects of the Brazilian identity, expressed in values, beliefs, actions, and prescriptions, such as laws.

Brazilian society has a dualistic nature in that its history alternated between authoritarian and liberal legislations, which varied in their assumptions and modes of action. Many rights were granted to Brazilians by rules although, in practice, they do not mean conquest from the popular strata, and many of the collective rights were acquired through a grant, object of 
demand of a minority representative of powerful strata that had political resource. However, the fact that they exist, even at the formal level, gives concreteness to public values, allowing them to become known and widely accepted and internalized, which thus represents a social heritage.

Machado-da-Silva et al. (2003) consider that formalism is an institution of Brazilian society, which includes formal aspects, such as expressions of the law, and the informal formalistic behavior of actors. Thus, the fact that many public values have been part of the rules copied from foreigners in the past may have allowed their perpetuity, even if formal, and these values may materialize at more favorable times throughout history. Therefore, looking at a particular rule allows us to identify such values and associate them with stages in the history of Brazilian Public Management.

Administrative contracts are inspired by French law. In principle, legislation makes a distinction between contracts of public origin and those of private origin. The striking distinctive feature is given by the supremacy of the public interest, which gives the public entity the prerogative to inspect the contracts themselves, to apply sanctions to the defaulting contractor, to unilaterally modify some of its clauses and even to terminate the administrative contract despite the will distinct from the particular. It can be said, that administrative contracts have regulatory clauses, which confer these distinctive features to such covenants, justified by the greater purpose that moves them, that is, the satisfaction of a public interest.

The margin of freedom between the parties to discipline contractual clauses is less, therefore, since the provisions of the legislation have a great influence on administrative contracts. It is the law, therefore, the first compass to guide these adjustments, which will have in the notice the peculiarities of each contract defined, always guided by legal precepts and public purposes that give meaning to such covenants.

\section{Categories Identification}

The resilient public values identified in the bureaucratic public management, management, and governance models are (1) dialogicity, (2) modernization, (3) efficiency, (4) productivity, and (5) professionalization.

Dialogicity is a public value of more recent concreteness, although it is present in the older liberal and more democratic texts, such as the Brazilian Constitution of 1934, which allowed for a parliamentary focus (Bastos, 2002).

Modernization is aligned with the search for the improvement of public service and the adequacy and improvement of collective goods, and, in this sense, has as its parameter private management represented by an effort to modernize the provision of public activities in the management model (Pinto \& Santos, 2017).

The overlapping public values of efficiency and productivity are believed to represent the efforts of the three models (rationallegal, managerial, and governance), varying in their modes of conception and achievement. In the Weberian model, efficiency is represented by standardization and thus the security that formalism brings. In the managerial model, efficiency is more aligned with achieving higher results with fewer resources, and finally, in the governance model, it can mean the effectiveness of a policy and the legitimacy it acquires; the term legitimacy is used here in the sense of adapting public policy to satisfy the aspirations of the community, in harmony with the conceptualization of Suchman (1995).

Lastly, professionalization is typical of the Weberian bureaucratic model and has been evident in the history of Brazilian public administration in the efforts toward career structuring, and the formation of a suitable technical body, since the 1936 reform (Pinto \& Santos, 2017).

Considering the comprehensive nature of the rules that discipline bids, their exceptions, and administrative contracts, we chose to analyze only the sections that disciplined the contracts. For a better understanding of the work performed, the following presents the data separated by rule. An analysis of the four rules mentioned in the methodology was conducted in order to verify if the public values are present in the texts of the rules. 


\section{Law No. 8,666 of 1993: General law for bidding and administrative contracts}

The general law on tenders and contracts covered the procurement procedures for works, services, and product purchases to meet the needs of the administration. It was also the rule that governed administrative contracts resulting from public tenders or legal exceptions to their execution. This rule was instituted in June 1993 and consists of 126 articles. According to Motta (2011), the bill that culminated in the general bidding law was widely debated by Congress for more than two years, as a text with democratic legitimacy, which constituted a significant institutional political advance. This bidding law was published under the Constitution of 1988. It is therefore natural that it has coherence in terms of the public values that it pursues.

The articles dealing with administrative contracts are located in Chapter III, Articles 54 to 88 . Although Law No. 8,666/93 has been amended through 28 laws since its original edition, the section on administrative contracts has undergone very few changes in seven of these amending laws. That is to say, only $25 \%$ of the rules that modified the law on bids and administrative contracts had any changes in the part concerning the latter. In fact, the Law No. 8,666 substituted the Decree-Law No. 2,300 of 1986, which had 30 articles on administrative contracts (from article 44 to 74 ). It was realized in many of the articles on Law No. 8,666 the permanence of general idea about the contracts existing in Decree-Law No. 2,300. The same text was seen in the two rules for many articles. The most visible changes are related to the requirements of transparency and about the penalization (fine) in some specific infractions. But, in general, the rules about administrative contracts were preserved from Decree-Law No. 2,300 to Law No. 8,666.

Analyzing only Law No. 8,666, it is possible to say that the rule has 34 articles dedicated to contracts, in which the following public values were identified: modernization, dialogicity, professionalization, productivity, and efficiency (Pinto \& Santos, 2017).

The public value of modernization has been inferred from the provisions concerning applied technology to produce and discipline the adjustments between the particular and the administration. Thus, it was observed that the contracts must take the written form, have a predetermined period of validity, and be numbered, dated, and signed. In addition, the chronological order of contracts must be respected, their statements must be published, and they must be consistent with the rules of civil law and general contract theory, which confers a rationality that aims to align this rule with others within the Brazilian legal system. It was also noted that any contractual amendment must be made in written form, with no acceptance of verbal adjustments.

The public value of dialogicity was observed in the concern with the clarity and precision of the stipulated rules, which gives transparency to the adjustments, thus allowing the interested parties to know in advance the rules of the contracts. In this sense, there was a concern that the record of occurrences was noted properly during the execution of the contracts, which would allow for proper supervision and security regarding the facts and decisions that may lead to the execution of the agreement. An interesting feature is that the state entity may punish the defaulting contractor. This fact should justify why there is such concern regarding the clauses recording the facts related to contractual execution, as this allows both the auditing of the decisions taken and the promoting of a defense against them. Similarly, the law prescribes that contract statements should be published, thus providing the public with important information about them and allowing citizens to control them. In this sense, there is alignment with the rules of the 1988 Constitution and the societal public administration model. Also, in the record of the public value in question, the modification of the contracts by adjustment between the parties was observed.

The public value of professionalization was observed in the rules that determine the detachment of certain professionals in taking care of adjustments, while striving for specialization and technicality. This rule requires that private agents stand out to talk to the administration and determines that each contract will have a manager and a supervisor, as representatives of the administration. Thus, it was observed that the law was concerned with determining that people with the necessary technical knowledge be selected to manage the contract, thus striving also for the public values of efficiency and productivity.

The public values of efficiency and productivity were observed at various times in the analyzed articles. As these contracts allow the public entity to supervise and punish the private entity, this clearly shows that contract performance should be guided by efficiency, at least in the sense of delivering what was required and offered. On the other hand, since the private entity does not want to suffer penalties, which may range from financial sanctions to embargoes on trade with public entities, it must drive a culture seeking efficiency, note that only empirical verification can actually verify this this statement. The rule prohibited the advance payment, stipulating that payment must be made after meeting the physical-financial schedule and allowing guarantees for the execution of the contracts. There was also a provision for 
verification of the realization of the object of the contract before releasing the contractor from the obligation assumed (by issuing the terms of receipt). In addition, there is a discipline regarding financial clauses, allowing for price reviews. This was understood as a concern with efficiency and productivity, as the unbalanced contract price imbalance may lead to the non-execution of the agreed object.

\section{Law No. 8,987 of 1995: general law of concessions}

This law was issued in February 1995 and is intended to govern the concession and permit regimes for public services. These are longer contracts, such as the concessions pertaining to land, water, and air transportation; funeral services; electricity; water; and sanitation. The rule has 47 articles in total, and it has undergone changes through four laws. There is provision for the application of the general rules provided for in Law No. 8,666 of 1993 for concessions and permits. Hence, where Law No. 8,987 of 1995 does not stipulate the rules, one must first seek to fill the gap through Law No. 8,666 of 1993 . The Concessions Act in Chapter VI deals with concession contracts, which were considered indispensable in the law of concessions and permissions of public services. Because there is a clear indication that the rules pertaining to administrative contracts generally apply to concessions and permits, it is possible to affirm the presence of the public values outlined in that rule. However, highlights were noted for some of these values in the provisions of Law No. 8,987 of 1995. The public value of modernization, for example, was verified by the mention expressed in the rule, being a concern, considered as something to be pursued in the provision of public service granted to the private individual.

In the same way, the concern with the quality of the service denotes having given priority to the public values of efficiency and productivity. In this sense, the rule requires stipulating criteria, indicators, formulas, and parameters that measure this quality. Also, in striving for efficiency, the concession law provided for the express liability of the individual for damages caused to users of the service, third parties, or even the public entity. Also, in view of efficiency and productivity, payments were foreseen through proof of compliance with the physical and financial schedule and the stipulation of guarantees to fulfill the obligations by the individual. In a more complex modeling, the rule allowed the individual to assign rights of credit in guarantee, with a view to obtaining financing, and, in this aspect, the rule strived for efficiency, increasing the possibility of compliance with the contract.

The public value of dialogicity was also observed by the provision of providing certificates of contract to anyone, as well as conferring alternative methods of conflict resolution, such as arbitration. The professionalization was verified in the establishment of a means of supervising the contracts and in the concern with the suitability of the particular service provider. The free access of public officials to all the information necessary for understanding the service also denotes transparency, thus aligning with the public value of dialogicity.

It has been observed that this rule deals with far more complex, longer-lasting contracts, in which it has become necessary to extend the scope of tools to the contracting parties, either by giving them greater freedom of action, on the one hand, or by providing for greater criteria of inspection, on the other hand. In concessions, private individuals may assume the management of public goods; in general, they make high investments, and, as they provide the public service in place of the entity holder of the duty to make available they enter more into the public sphere, assuming, to some extent, a public function (Bandeira-de-Mello, 1983), resembling, in this respect, the contracting public agency. Hence, the complexity of the contractual model of concessions may explain the expansion of tools that are evident in representing the values of dialogicity, efficiency, and productivity.

\section{Law No. 11,079 of 2004: law of PPP}

Law No. 11,079 of 2004 established the regime of public-private partnerships in Brazil. The rule has 30 articles, and since its December 2004 edition, has been modified by seven other laws. Public-private partnerships are special concessions characterized by the presence of public works, besides the granting of the public service and its subdivisions in the sponsored and administrative forms. In the sponsored form, in addition to being remunerated by the tariff, which is paid by the user of the service, the state entity pays the individual through contribution and/or additional consideration to the tariff (Law No. 11,079 of 2004). In the administrative form, the public entity is the immediate beneficiary of the object of the PPP (Law No. 11,079 of 2004). The law expressly mentions the application of provisions of the General Concessions Act (Law No. 8,987 of 1995) to PPPs and also mentions the application of the provisions of Law No. 8,666 of 1993 to such contracts. Chapter II of Law No. 11,079 of 2004, Articles 5 and 6 , provides for the specific rules concerning PPP contracts. 
The public values of efficiency and productivity take precedence, notably in the prediction that PPPs should seek socioeconomic advantages, that they must have financial sustainability, that there should be guarantees compatible with the existing risks in the service, and that there should be profit sharing, private partner performance appraisal, variable remuneration, and possible retention of payments by the public to the private partner, among others. The modernization value has also received shelter, notably due to the prediction that services should prevail today.

Dialogicity also received attention in the PPP contract. In this sense, there is provision for conflict resolution through private mechanisms, such as arbitration. When the contract is made, it must be submitted for public consultation, which allows the participation of citizens. In addition, the transparency of procedures and decisions was indicated as one of the guidelines of the rule. The professionalization, in turn, was observed by the prediction that the public agency should use a technical support structure for the performance of its functions.

\section{Bill No. 4,253 of 2020 and Law No. 14,133, from 01.04.2021}

Law No. 8,666 is also on the way to extinction. In February 2021, Law Project No. 4,253 of 2020 followed for the sanction of the President of the Republic, which was converted into Law No. 14,133, of April 1, 2021. The text of Law No. 8,666 will be gradually revoked. Law No. 14,133 provides for the automatic revocation of the provisions relating to crimes, provided for in Law No. 8,666 of 1993. It is also stated that the contracts entered under Law No. 8,666 of 1993, will be governed, during its validity, by the rules of Law No. 8,666 of 1993. It is also said that, within 2 years of the publication of Law No. 14,133, the text of Law No. 8,666 will lose its effectiveness.

Thus, between April 1, 2021 and March 31, 2023, there will be, for administrative contracts, the possibility of adopting the rules provided for in Law No. 8,666 or the new rules provided for in Law No. 14,133. After March 31, 2023, the text of Law No. 8,666 will lose its validity in its entirety. Thus, it was analyzed the text of Law Project No. 4,253 of 2020, converted into Law No. 14,133 of 2021, which will be addressed only by the definitive provision, that is, by the number of Law No. 14,133. Regarding administrative contracts, it was found that many of the provisions that previously existed in Law No. 8,666 came to exist within the text of the new law. The chapter dealing with administrative contracts in Law No. 14,133 has 65 articles (from article 89 to article 154) and there is a transformation in the legislation, also striving for the resilience of public values already identified in the legislation in force.

The modernization public value was verified by the permanence of the rules already foreseen in Law No. 8,666, with some details, such as the admission of the electronic form of agreement, the admission of confidential contracts, if essential to the security of society and the State. Dialogicity is a public value that has led to many changes in the new rule. Emphasis is given to the allocation of contractual risks, which may be shared or supported by the Administration or by the individual, case by case. The provision of arbitration, conciliation, and mediation as a means of resolving disputes is also in line with dialogicity, as it symbolizes the joint effort between the parties to eliminate contractual problems, thus avoiding the search for the Judiciary.

Also worthy of mention are the situations related to advertising, which are disciplined throughout the text, which, due to the duty of transparency, bring society closer to the execution of contracts. Professionalization was also verified, for example, in article 117 of Law No. 14,133, which requires the presence of inspectors to monitor the execution of contracts. Law No. 14,133 also requires that people dealing with tenders and contracts have specific training. Competency Management is an express requirement of the rule. The disclosure to the public of reasons and of the person responsible for the work stoppage is also planned and is in line with this public value.

Likewise, Law No. 14,133 requires that the contractor has a representative and that the dialogue between the parties is always formalized when there are complaints, and the Administration must make decisions. The public values efficiency and productivity were considered in several provisions of Law No. 14,133 of 2021. In relation to contracts, there was, for example, an expansion of the approach related to the facilitation of situations related to payments, such as in case of contractual imbalance effectively verified, as well as the possibility of indemnities, avoiding unnecessary clashes and administrative procedures.

Risk management is also in line with these public values, because it aims to achieve the best contractual results and avoid problems in execution. Likewise, the automatic extension of contractual deadlines in the face of problems, with public indication of those responsible is something that can increase efficiency due to the pedagogical and inhibitory effects. 
These are findings of the permanence of public values identified in the literature and present in the prescriptions of Law No. 14,133 of 2021, which replaces Law No. 8,666 in the governing of administrative contracts. It was verified the resilience of the public values identified in the research, and the primacy for some of them, like the public values dialogicity, efficiency and productivity.

\section{DISCUSSION}

In the laws on administrative contracts, concessions, and PPPs, the presence of the five public values attributed to public administration management models was observed, that is, dialogicity, modernization, efficiency, productivity, and professionalization (Pinto \& Santos, 2017). Such public values, as verified, permeate the models of bureaucratic administration, management, and public governance.

In the analyzed rules, the presence of the characteristics of bureaucratic and managerial models was remarkable. This is due to the very conception of administrative contracts, which are formal instruments by nature, whose source is the written rules, as disciplined in the texts analyzed. It is possible to affirm an improvement in the discipline of administrative contracts, striving for professionalization and modernization. Thus, the characteristics of formality, transparency, and predictability of decisions capable of conferring security to the participants align with the characteristics of the bureaucratic management model.

Nevertheless, the traits of the management model were also verified, notably by the primacy given to the public values of efficiency and productivity. The rules related to performance control, supervision, attention to financial clauses, and the proper punishment of individuals are indicative of the search for results and productivity as an end (understood as the public interest to be satisfied by the contract). Similarly, the supervision and prosecution of defaulting contractors aligns with accountability, which is one of the vectors of managerialism. One must not forget also the concern with the specialization and capacity of managers and supervisors, which also aligns with the public value of efficiency.

In turn, the clauses related to transparency, contract publicity, and the exercise of control, especially by citizens, are indicators of the presence of the model of Societal Public Administration, in which participatory and democratic management brings citizens closer, in both the public and private arenas.

Therefore, it was verified that the contract instrument is a technology that keeps in its rules the traces of the public administration models that occurred in Brazil. As such, it values transparency, clarity of information, allowing for certainty about decision-making and the very predictability of such decisions. At this point, it prioritizes security in contractual relationships, and its conception is strictly in line with the bureaucratic model, especially regarding formality and technicality. Similarly, the concern with efficiency highlights the presence of the management model, in addition to the clauses related to advertising, which allow control, to privilege the model of Societal Administration.

\section{FINAL CONSIDERATIONS}

The research identified the public values that permeated the management models that have occurred in the Brazilian Public Administration, that is, the bureaucratic, managerial, and public governance models (Secchi, 2009). Likewise, it identified such public values, namely, modernization, professionalization, dialogicity, efficiency, and productivity in the rules pertaining to administrative contracts (general procurement law, general concessions law, and PPP law).

In addition, the research considered some cultural characteristics of Brazilian society, such as patrimonialism and, for example, the way in which it was not possible to immediately verify a relationship between such traits and the public values identified. However, dualism and formalism, traits that were pointed out as characteristics of Brazilian society, may explain the presence of such public values in ancient texts, as in the case of more democratic political texts since the first republic, and of management reforms that have been implemented since 1936, in contradiction with an often authoritarian and centralizing reality. In other words, the existence of rules that gave relevance to such public values allowed persistent movements towards them, until the advent of the 1988 Constitution and the last management reform, which led to more significant changes in public management, according to Pinto and dos Silva (2017). 
The presence of such values in Constitutions, the primeval effort for administrative reforms in 1936 and 1967 and until the 1995 reform, and the advances in public management that have been recorded are indications of the resilience of public values that are being added to the normative collection of Brazilian society and the mode of action of public managers. By entering the collection of norms and beliefs, these values give their own contours to the management and shape the identity of the Brazilian Public Administration. Therefore, it can be understood that there is a public ethos that manifests itself in prescriptions, processes, and actions.

As a limitation to the present study, the joviality of the three rules analyzed can be affirmed, since all of them were published after the constitution of 1988, a positive political text in terms of promoting managerial and governance reform, more recent phenomena in the trajectory of Public Administration. As recommendations for future studies, it is suggested to analyze the resilience of public values in other forms of relationships with public administration, such as the terms of partnership, the terms of development, the terms of cooperation, and the covenants. At this point, the respective rules are more recent than those of administrative contracts and may therefore be more revealing of the resilience of values and the cultural aspects present in the formation of laws.

\section{ACKNOWLEDGMENTS}

The authors wish to thank the Brazilian National Research Council (CNPq) for the research funding, coordinated by professor Mayla Cristina Costa Maroni Saraiva, and the Partners Organizations, Federal Paraná University, Positivo University and IBEPES. Universal Edital - Process 421753/2016-1. 


\section{REFERENCES}

Abu-El-Haj, J. (2005). Da "Era Vargas" à FHC: transições políticas e reformas administrativas. Revista de Ciências Sociais, 36(1/2), 33-51.

Almeida, L. A., \& Gomes, R. C. (2019). Perspectivas Teóricas para a Análise de Políticas Públicas: Como Lidam com a Complexidade? Administração Pública e Gestão Social, 11(1), 16-27.

Bandeira-de-Mello. C. A. D. (1983). Regime constitucional dos servidores da administração direta e indireta. São Paulo, SP: Malheiros.

Bardin, L. (2011). Análise de conteúdo. Lisboa, Portugal: Edições 70.

Bastos, C. (2002). As modernas formas de violência e a crise dos valores constitucionais. Revista CEJ, 6(18), 34-37.

Berger, P. L., \& Luckmann, T. (1985). A construção social da realidade: tratado de sociologia do conhecimento. Petrópolis, RJ: Vozes.

Brasil, F. G., Cepêda, V. A., \& Medeiros, T. B. (2014). O DASP e a formação de um pensamento político-administrativo na década de 1930 no Brasil. Temas de Administração Pública, 9(1), 60-90.

Bresser-Pereira, L. C., Jalkauska, M., \& Ribeiro, R. (1996). Crise econômica e reforma do Estado no Brasil: para uma nova interpretação da América Latina. São Paulo, SP: Editora 34.

Caillé, A. (2008). Reconhecimento e sociologia. Revista brasileira de ciências sociais, 23(66), 151-163.

Calmon, P. (2002). História Social do Brasil: A época republicana (Vol. 3). São Paulo, SP: Martins Fontes.

Campbell, J. L. (2002). Ideas, politics, and public policy. Annual review of sociology, 28(1), 21-38.

Carvalho, J. M. D. (1997). Mandonismo, coronelismo, clientelismo: uma discussão conceitual. Dados, 40(2), 1678-4588.

Castor B. V. J. (2013). Mudança depende de vontade política e reformas. In R. C. R. Loures, M. M. Schlemm, V. B. J. Castor (Orgs.), Para o Brasil Voltar a Crescer: evidências, reflexões e caminhos (pp. 182-195). Curitiba, PR: Itersaberes.

Coraiola, D. M., Foster, W. M., \& Suddaby, R. (2015). Varieties of history in organization studies. In P. G. McLaren, A. J. Mills, \& T. G. Weatherbee (Eds.), The Routledge Companion to management \& organizational history (pp. 206-221). New York, NY: Routledge.

Coraiola, D. M., Jacometti, M., Baratter, M. A., \& Gonçalves, S. A. (2015). Conciliando agência e contexto na dinâmica da mudança institucional. Cadernos EBAPE.BR, 13(4), 701-726.

Costa, F. L. D. (2008). Brasil: 200 anos de Estado; 200 anos de administração pública; 200 anos de reformas. Revista Administração Pública, 42(5), 829-874.

Davis, G. F., \& Scott, W. R. (2007). Organizations and organizing: Rational, natural, and open system perspectives. Upper Saddle River, NJ: Prentice Hall.

Decreto-lei no 200, de 25 de fevereiro de 1967. (1967). Dispõe sôbre a organização da Administração Federal, estabelece diretrizes para a Reforma Administrativa e dá outras providências. Brasília, DF. Retrieved from http://www.planalto.gov.br/ccivil_03/decreto-lei/ del0200.htm
Decreto-lei no 2.300, de 21 de novembro de 1986. (1986). Dispõe sobre licitações e contratos da Administração Federal e dá outras providências. Brasília, DF. Retrieved from http://www. planalto.gov. br/ccivil_03/decreto-lei/Del2300-86.htm

Dellagnelo, E. L., \& Machado-da-Silva, C. L. (2000). Novas formas organizacionais: onde se encontram as evidências empíricas de ruptura com o modelo burocrático de organizações? Organizações \& Sociedade, 7(19), 19-33.

Deephouse, D. L., Bundy, J., Tost, L. P., \& Suchman, M. C. (2017). Organizational legitimacy: Six key questions. The SAGE handbook of organizational institutionalism, 4(2), 27-54.

Fernandes, F. (1997) A reconstrução da realidade nas ciências sociais. Mediações. Revista de Ciências Sociais, 2(1), 1-37.

Gurgel, C. R. M. (2017). Para Além da Reforma do Estado-crises e limites da razão liberal. Administração Pública e Gestão Social, 9(3), 159-170.

Haveman, H. A., \& Gualtieri, G. (2017). Institutional Logics. In R. J. Aldag (Ed.), Oxford research encyclopaedia of business and management. Oxford, UK: Oxford University Press.

Holanda, S. B., Eulálio, A., \& Ribeiro, L. G. (1995). Raízes do brasil. São Paulo, SP: Companhia das Letras.

Keinert, T. M. M. (1994). Os paradigmas da administração pública no Brasil (1900-92). Revista de Administração de Empresas, 34(3), 41-48.

Lavalle, A. G. (2001). Espaço e Vida Públicos: reflexões teóricas e sobre o pensamento brasileiro (Doctoral Dissertation). Universidade de São Paulo, São Paulo, SP.

Lei no 8.666, de 21 de junho de 1993. (1993). Regulamenta o art. 37, inciso XXI, da Constituição Federal, institui normas para licitações e contratos da Administração Pública e dá outras providências. Brasília, DF. Retrieved from http://www.planalto.gov.br/ccivil_03/ leis/I8666cons.htm

Lei no 8.974, de 05 de janeiro de 1995. (1995). Regulamenta os incisos II e V do § 10 do art. 225 da Constituição Federal, estabelece normas para o uso das técnicas de engenharia genética e liberação no meio ambiente de organismos geneticamente modificados, autoriza o Poder Executivo a criar, no âmbito da Presidência da República, a Comissão Técnica Nacional de Biossegurança, e dá outras providências. Brasília, DF. Retrieved from http://www.planalto.gov.br/ccivil_03/ leis/I8974.htm

Lei no 8.987, de 13 de fevereiro de 1995. (1995). Dispõe sobre o regime de concessão e permissão da prestação de serviços públicos previsto no art. 175 da Constituição Federal, e dá outras providências. Brasília, DF. Retrieved from http://www.planalto.gov.br/ccivil_03/ leis//8987compilada.htm

Lei no 11.079, de 30 de dezembro de 2004. (2004). Institui normas gerais para licitação e contratação de parceria público-privada no âmbito da administração pública. Brasília, DF. Retrieved from http:// www.planalto.gov.br/ccivil_03/_ato2004-2006/2004/lei/l11079.htm 
Lei no 14.133, de 01 de abril de 2021. (2021). Lei de Licitações e Contratos Administrativos. Brasília, DF. Retrieved from http://www. planalto.gov.br/ccivil_03/_ato2019-2022/2021/lei/L14133.htm

Machado-da-Silva, C. L., Guarido, E. R., Filho, Nascimento, M. D., \& Oliveira, P. T. (2003). Institucionalização da mudança na sociedade brasileira: o papel do formalismo. In M. M. F. Vieira, \& C. A. Carvalho (Org.), Organizações, instituições e poder no Brasil (Vol. 1, Cap. 6, pp. 179-202). Rio de Janeiro, RJ: Editora FGV.

Mahoney, J., \& Thelen, K. (2010). A theory of gradual institutional change. Explaining institutional change: Ambiguity, agency, and power (Vol.1, Cap. 1, pp. 1-37). New York, NY: Cambridge University Press.

Matta, R. (1986). Explorações: ensaios de sociologia interpretativa. Rio de Janeiro, RJ: Rocco.

Moore, M. H. (2007). Criando valor público por meio de parcerias público-privadas. Revista do Serviço Público, 58(2), 151-179.

Motta, C. P. C. (2011). Eficácia nas licitações e contratos: estudos e comentários sobre as leis 8.666/93 e 8.987/95, a nova modalidade do pregão e o pregão eletrônico; impactos da lei de responsabilidade fiscal, legislação, doutrina e jurisprudência (Vol. 1, 12a ed.). Belo Horizonte, MG: Del Rey.

Oliveira, M. C., \& Gimenes, É. R. (2010). A construção dos conceitos de público e privado no brasil, segundo autores clássicos do pensamento social brasileiro: uma interpretação sobre o cenário de ação do terceiro setor. Caderno de Administração, 17(2), 84-94.

Pinto, J. F, \& Santos, L. T. (2017). Administração Pública Brasileira no Século XXI: caminhamos para alguma reforma? Administração Pública e Gestão Social, 9(3), 205-215.

Prestes-Motta, F. C. P., \& Alcadipani, R. (1999). Jeitinho brasileiro, controle social e competição. Revista de Administração de Empresas, 39(1), 6-12.

Projeto de Lei $n^{\circ} 4.253$, de 2020. (2020). Estabelece normas gerais de licitações e contratos administrativos para a União, Estados e Municípios, e suas autarquias e fundações. Disciplina prerrogativas, alocação de riscos, arbitragem, impugnações, recursos, fiscalização e prevê crimes. Cria o Portal Nacional de Contratações Públicas (PNCP) e centrais de compras. Brasília, DF. Retrieved from https://www25. senado.leg.br/web/atividade/materias/-/materia/145636
Ribeiro, D., \& Brasileiro, O. P. (1995). O povo brasileiro; a formação e o sentido do Brasil. São Paulo, SP: Companhia das Letras.

Sabatier, P. A. (2007). Theories of the Policy Process (2a ed.). Boulder, CO: Westview Press.

Scott, W. R. (2014). W. Richard SCOTT (1995), Institutions and Organizations. Ideas, Interests and Identities.M@n@gement, 17(2), 136-140.

Scott, W. R., \& Meyer, J. W. (1994). Environmental linkages and organizational complexity. Public and private schools In W. R, Scott, \& J. W. Meyer (Eds.), Institutional Environments and Organizations. Structural Complexity and Individualism (pp. 137-59). Thousand Oaks, CA: Sage.

Secchi, L. (2009). Modelos organizacionais e reformas da administração pública. Revista de Administração Pública, 43(2), 347-369.

Souza, C. M. D. (2003). “Estado do campo" da pesquisa em políticas públicas no Brasil. Revista Brasileira de Ciências Sociais, 18(51), 15-19.

Streeck, W., \& Thelen, K. A. (Eds.). (2005). Beyond continuity: Institutional change in advanced political economies. Oxford, UK: Oxford University Press.

Suchman, M. C. (1995). Managing legitimacy: Strategic and institutional approaches. Academy of management review, 20(3), 571-610.

Suddaby, R., \& Greenwood, R. (2009). Methodological issues in researching institutional change. In D. Buchanan, \& A. Bryman (Eds.), The Sage handbook of organizational research methods (pp. 177195). London, UK: Sage.

Thies, C. G. (2002) A pragmatic guide to qualitative historical analysis in the Study of international relations. International Studies Perspecftives, 3(4), 351-372.

Tuchman, G (1994) Historical Social Science: Methodology, methods, and meanings. In N. K. Denzin, \& Y. S. Lincoln (Eds.), Handbook of Qualitative Research. Thousand Oaks, CA: SAGE.

Vergara, S. (2005). Métodos de Pesquisa em Administração. São Paulo, SP: Editora Atlas.

Viana, O. (2005). Populações Meridionais do Brasil (Edições do Senado Federal, vol. 27). Brasília, DF: Conselho Editorial do Senado Federal. 
Fernanda Alves Andrade Guarido

ORCID: https://orcid.org/0000-0001-9910-5299

Post-Doctor in Law from the Pontifical Catholic University of Paraná (PUCPR); Ph.D. and Master in Business Administration from Universidade Positivo; Professor at the Law Course at FAE Centro Universitário; Lawyer. E-mail: faa1807@gmail.com

Eloy Eros da Silva Nogueira ORCID: https://orcid.org/0000-0002-5234-496X

Professor and Researcher associated with the Research Group on Practices, Subjectivity and Organizations by the Master and Doctorate Program in Administration at Positivo University E-mail: esn.ipe777@gmail.com

\section{Mayla Cristina Costa Maroni Saraiva}

ORCID: https://orcid.org/0000-0002-2909-3103

Post-Doctor in Administration from the Federal University of Uberlândia (UFU); Associate Professor at the Department of Accounting and Actuarial Sciences at the University of Brasília (UnB). E-mail: mayla.c.costa@gmail.com 